\title{
Jubileusz 150-lecia Warszawskiego Szpitala dla Dzieci, Warszawa, 25 października 2019 roku (Anna Marek)
}

W 14 numerze „Gazety Lekarskiej” z 1869 r. ukazała się krótka notatka informująca, że 23 września otwarty został w Warszawie przy ul. Solnej 814 Zakład Leczniczy dla Dzieci dr. Sikorskiego. W zakładzie znajdowały się łóżka dla chorych na odrę, szkarlatynę i ospę oraz oddziały chirurgiczny i wewnętrzny. W placówce udzielano pomocy lekarskiej wszystkim dzieciom za niewielką opłatą, a dzieci ubogich rodziców przyjmowano za darmo. Opiekę pielęgniarską sprawowały szarytki - siostry miłosierdzia.

Z każdym rokiem w Zakładzie przyjmowano coraz więcej pacjentów i szybko okazało się, że placówka nie może sprostać oczekiwaniom warszawskich dzieci. Rozpoczęto zatem poszukiwania nieruchomości, na której planowano postawić większy budynek. 3 (15) maja $1874 \mathrm{r}$. położono kamień węgielny pod budowę nowego szpitala na działce przy ul. Aleksandrii (dziś ul. Kopernika) pod numerem 2768ac. 6 (18) listopada $1875 \mathrm{r}$. gmach został uroczyście otwarty przez hrabinę Aleksandrę Potocką, główną fundatorkę szpitala. Od początku swojego istnienia szpital przy ul. Kopernika działał dzięki ofiarności warszawiaków. Hojni dobroczyńcy wykupywali tzw. łóżka wieczyste, czyli sponsorowali leczenie pacjentów leżących na konkretnym łóżku.

Szpital cieszył się wśród warszawiaków dużą popularnością, mimo że borykał się z licznymi problemami. W tym $\mathrm{z}$ wiecznym brakiem środków finansowych, co utrudniało przebudowy oraz remonty poszczególnych oddziałów. Pomimo jednak tych trudności, a także faktu, iż powstawały w mieście kolejne placówki dziecięce - szpitale dziecięce: Karola i Marii, Bersonów i Baumanów oraz ośrodek przy ul. Litewskiej, to właśnie szpital na Kopernika stał się kuźnią przyszłych specjalistów zajmujących się pediatrią oraz chirurgią dziecięcą.

Kolejne lata to okres I wojny światowej i kryzysu. Ogromna bieda i niedostatek finansowy utrudniały pracę szpitala, jednakże z zawieruchy wojennej szpital wyszedł z nienaruszonym stanem budynków i mienia ruchomego. Dopiero w 1933 r. uzyskał podstawy finansowe i nowy statut, według którego stał się własnością fundacji i korzystał 
z jej majątku. Rozbudowano i wyremontowano wszystkie oddziały oraz otworzono 16-łóżkowy oddział dla niemowląt. Ogółem w szpitalu znajdowało się 200 łóżek. W szpitalu prowadzona była też działalność naukowo-dydaktyczna, między innymi zajęcia z zakresu chorób wieku dziecięcego dla studentów IV i V roku wydziału lekarskiego Uniwersytetu Warszawskiego.

Podczas okupacji na terenie szpitala prowadzono zajęcia z medycyny w ramach tajnych kompletów oraz punkt krwiodawstwa. Dawcy zrekrutowali się głównie spośród studentów Szkoły dr. Zaorskiego. Pracownicy szpitala uczestniczyli też $\mathrm{w}$ ratowaniu dzieci z Zamojszczyzny, wykupionych z wagonów od niemieckiej eskorty, a wywożonych do Rzeszy w celach germanizacyjnych. W placówce zapewniono im opiekę i wyżywienie, a później kierowano do bezpiecznych miejsc pobytu. W czasie powstania warszawskiego ośrodek pełnił obowiązki szpitala powstańczego, którego komendantem był dr Zbigniew Tabeński. 24 września $1944 \mathrm{r}$. władze niemieckie zarządziły ewakuację szpitala. Pracownicy i chore dzieci po wielu perturbacjach znalazły spokojne miejsce pobytu aż w Bukowinie Tatrzańskiej.

W wyniku działań wojennych zabudowania uległy zniszczeniu, ocalał tylko budynek główny. Po wojnie szpital wznowił działalność już 20 listopada 1945 r. jako Miejski Szpital Dziecięcy nr $1 \mathrm{w}$ Warszawie. Jako pierwszy rozpoczął działalność oddział chirurgiczny, stopniowo uruchamiano kolejne oddziały - niemowlęcy, pediatryczny, nefrologiczny, laryngologiczny i liczne poradnie. W szpitalu prowadzono również działalność naukowo-dydaktyczną. W oddziale pediatrycznym odbywały się zajęcia ze studentami III roku Akademii Medycznej oraz egzaminy specjalizacyjne. $Z$ kolei w oddziale chirurgicznym prowadzono szkolenia dla pediatrów, chirurgów ogólnych i ortopedów na I i II stopień specjalizacji.

W przeciągu ostatnich 10 lat szpital przeszedł gruntowną modernizację. W 2012 r. oddano do użytku nowy budynek, w którym rozpoczął działalność Ośrodek Dziennej Rehabilitacji Narządu Ruchu, Oddział Pediatrii oraz przychodnie przyszpitalne. W maju 2015 r. ukończono budowę kolejnego pawilonu, w którym zlokalizowano sale operacyjne, Oddział Dziennej Rehabilitacji Neurologicznej i pracownie diagnostyczne. Cztery lata później zakończono remont zabytkowego budynku, gdzie znalazł swoje miejsce Oddział Chirurgii oraz administracja Szpitala.

25 października 2019 r. w Warszawskim Domu Technika NOT przy ul. Czackiego 3/5 odbyły się uroczystości 150-lecia istnienia Warszaw- 
skiego Szpitala dla Dzieci. Współorganizatorem obchodów jubileuszu był Urząd Marszałkowski Województwa Mazowieckiego. Patronat honorowy nad obchodami objął Prezydent Miasta Stołecznego Warszawy. Oprócz pana Prezydenta Rafała Trzaskowskiego wśród zaproszonych gości znaleźli się: pani Aleksandra Gajewska - poseł elekt na Sejm Rzeczypospolitej Polskiej, pani Elżbieta Lanc - członek Zarządu Województwa Mazowieckiego, pan Aleksander Ferens - Burmistrz Dzielnicy Śródmieście oraz pan Paweł Lech - Przewodniczący Komisji Zdrowia Rady Miasta st. Warszawy. Uroczystość zaszczycili przedstawiciele jednostek organizacyjnych miasta stołecznego Warszawy: Dyrektor Biura Polityki Zdrowotnej - Pan Paweł Chęciński, Członek Zarządu Spółki Tramwaje Warszawskie - Pan Robert Kościelny, Dyrektor Centrum Aktywności Międzypokoleniowej „Nowolipie” - Pani Joanna Dolińska-Dobek, Dyrektora Muzeum Powstania Warszawskiego, reprezentował Pan Jan Radziukiewicz, kierownik działu Archiwum Historii Mówionej. Przybyli również konsultanci wojewódzcy w dziedzinie: chirurgii dziecięcej - prof. Beata Jurkiewicz, ortopedii i traumatologii - dr Paweł Skowronek i pielęgniarstwa epidemiologicznego - Małgorzata Giemza oraz prezes Naczelnej Rady Pielęgniarek i Położnych - Zofia Małas, Prezes Okręgowej Rady Lekarskiej - Łukasz Jankowski, Przewodnicząca Warszawskiej Okręgowej Rady Pielęgniarek i Położnych - Anna Dudzińska, a także przedstawiciele środowiska naukowego oraz dyrektorzy zaprzyjaźnionych szpitali. Nie zabrakło na spotkaniu dawnych pracowników szpitala, którzy dziś z sentymentem wspominają pracę w placówce. Podczas spotkania wysłuchano wystąpienia Prezydenta miasta stołecznego Warszawy Pana Rafała Trzaskowskiego, Członka Zarządu Województwa Mazowieckiego Pani Elżbiety Lanc i innych gości, odczytano również listy gratulacyjne. Wyróżnieni pracownicy otrzymali odznaki honorowe Ministra Zdrowia „Za zasługi dla ochrony zdrowia”, wyróżnienia okolicznościowe Prezydenta m.st. Warszawy „Za zasługi dla ochrony zdrowia w Mieście Stołecznym Warszawie”, a także dyplomy Dyrektor Szpitala. Za wszystkich byłych i obecnych pracowników szpitala wzniesiono toast lampką szampana. Był też okolicznościowy tort i wystawny obiad.

Przed uroczystością w Kościele pod wezwaniem św. Krzyża na Krakowskim Przedmieściu odprawiono mszę świętą w intencji byłych i obecnych pracowników szpitala. Następnie w absydzie szpitalnego budynku głównego odsłonięto tablicę „W hołdzie wszystkim, którzy mieli udział $\mathrm{w}$ ratowaniu życia i przywracaniu zdrowia pacjentom Warszawskiego Szpitala dla Dzieci w latach 1869-2019”, ufundowa- 


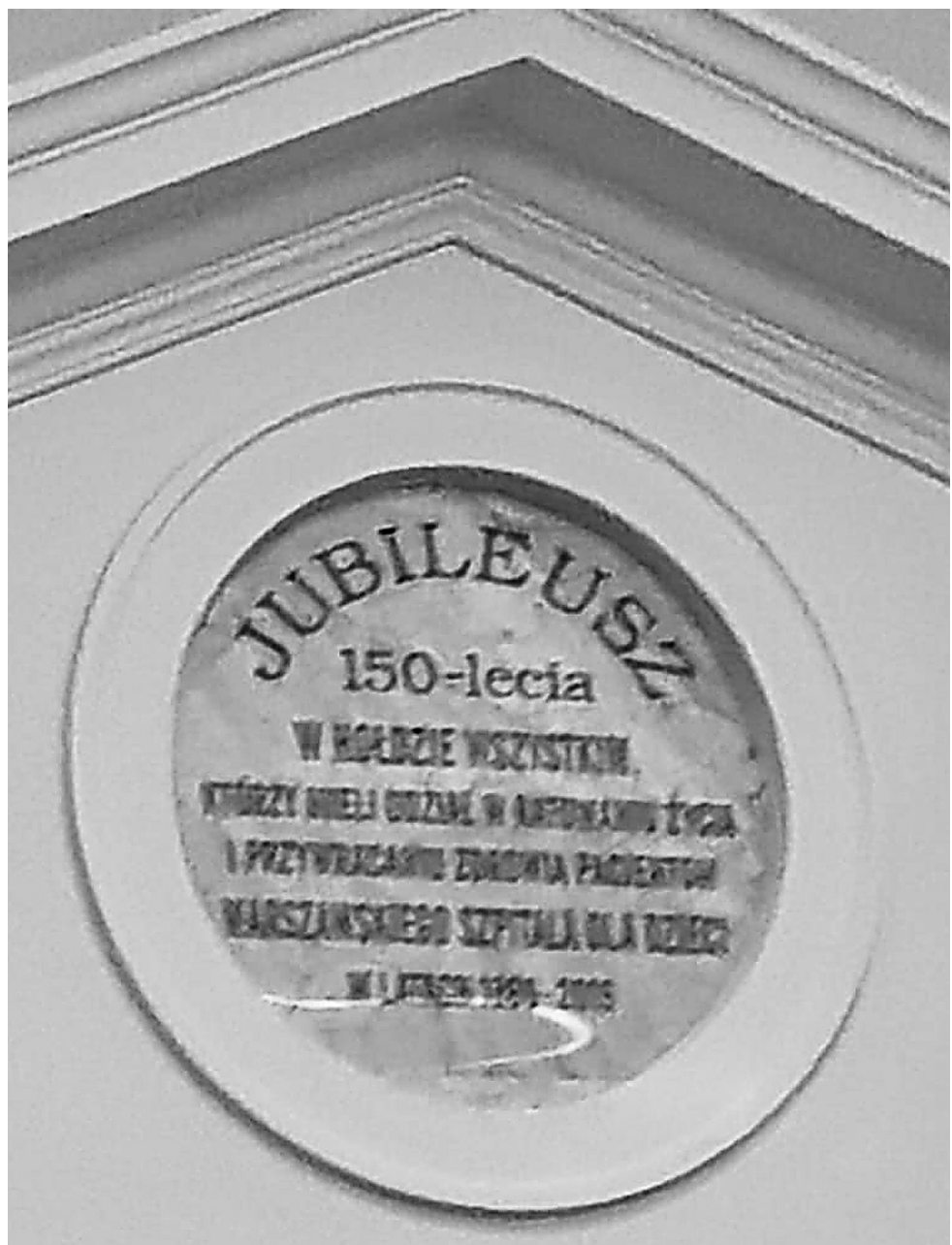

Fot. 1. Tablica $w$ absydzie szpitalnego budynku głównego „W hołdzie wszystkim, którzy mieli udział w ratowaniu życia i przywracaniu zdrowia pacjentom Warszawskiego Szpitala dla Dzieci w latach 1869-2019", ufundowana przez Dyrektora Szpitala Izabelę Marcewicz-Jendrysik. Fot. Renata Gut

ną przez Izabelę Marcewicz-Jendrysik - Dyrektora Szpitala. Z okazji jubileuszu powstał film zrealizowany przez Muzeum Powstania Warszawskiego (zob. Facebook - Warszawski Szpital dla Dzieci), wydano również okolicznościową gazetę, pocztówki z archiwalnymi zdjęciami oraz przygotowano specjalny medal, który otrzymał każdy zaproszony gość. 

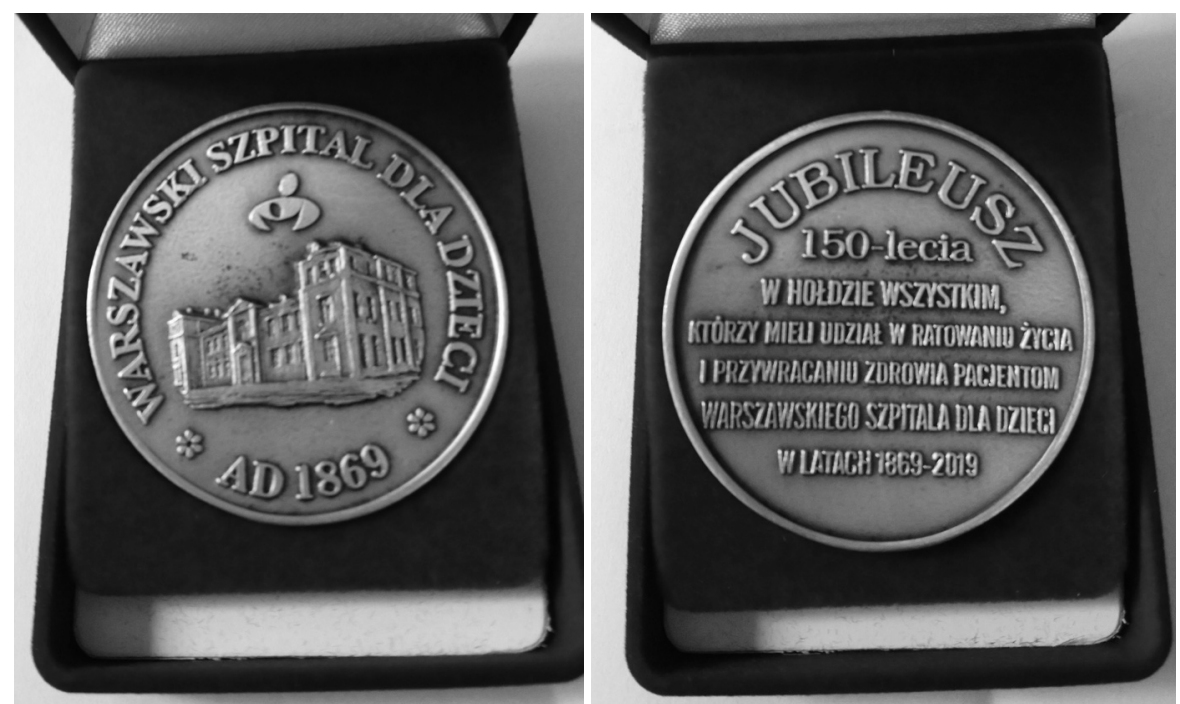

Fot. 2. Medal okolicznościowy. Fot. Anna Marek

W ramach obchodów 150-lecia istnienia placówki przeprowadzano też akcje promujące zachowania prozdrowotne. 27 czerwca rozpoczęła się akcja „150 litrów krwi na 150-lecie Warszawskiego Szpitala dla Dzieci”, w ramach której pracownicy postanowili podarować potrzebującym pacjentom 150 litrów krwi. Natomiast z okazji obchodzonego 15 października Światowego Dnia Mycia Rąk na fasadzie budynku przygotowano okolicznościową iluminację, a w internecie i na monitorach w Tramwajach Warszawskich można było obejrzeć spot promujący higienę rąk. Pracownicy szpitala przekonywali również mieszkańców w centrum Warszawy do badań mikrobiologicznych rąk.

Szpital wspierany jest również przez różne organizacje, które pragnęły w tym tak ważnym roku podkreślić związek z placówką. „Dobrzy Ludzie - kibice Legii dzieciom” z okazji jubileuszu zdecydowali się przekazać szpitalowi nowy ambulans do przewozu dzieci - w dalszym ciągu prowadzą zbiórkę środków na ten cel. Fundacja „Zaczytani.org” wraz ze swoimi ambasadorami ofiarowała szpitalowi swoją 1000. „zaczytaną bibliotekę". W oddziale chirurgii i ortopedii już niebawem zostanie odsłonięty obraz namalowany na podstawie trójwymiarowych makiet z plasteliny, wykonanych przez pacjentów pod okiem artystów z Fundacji „Obraz w pigułce”, a uczestnicy Warsztatów Terapii Zajęciowej ze Stowarzyszenia Otwarte Drzwi podarowali szpitalowi własnoręcznie wykonaną kartkę urodzinową. 


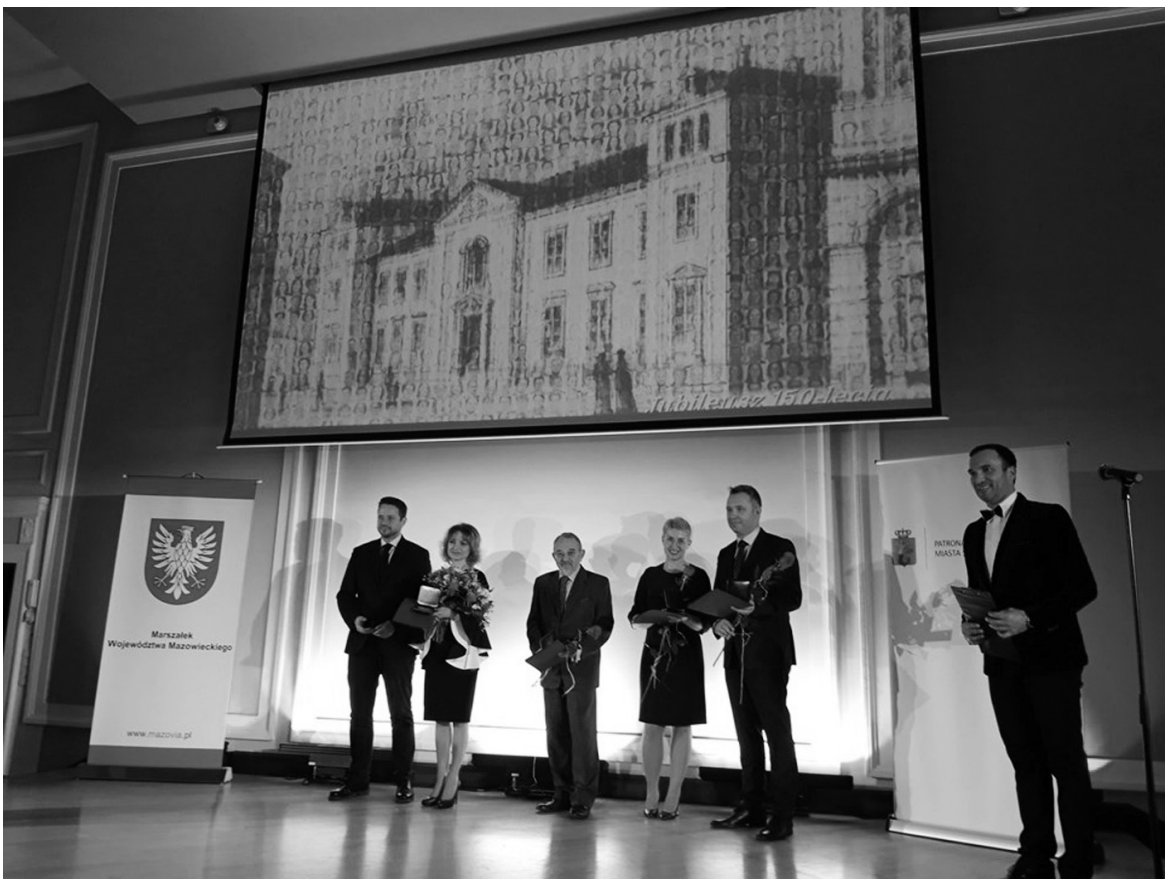

Fot. 3. Uroczystość 150-lecia szpitala. Od lewej: Prezydent Warszawy Rafał Trzaskowski, Dyrektor Szpitala Izabela Marcewicz-Jendrysik, dr Marcin Rawicz, dr Agnieszka Wypych, mgr Maciej Wiśniewski, Jacek Barczak. Fot. Mateusz Modrak

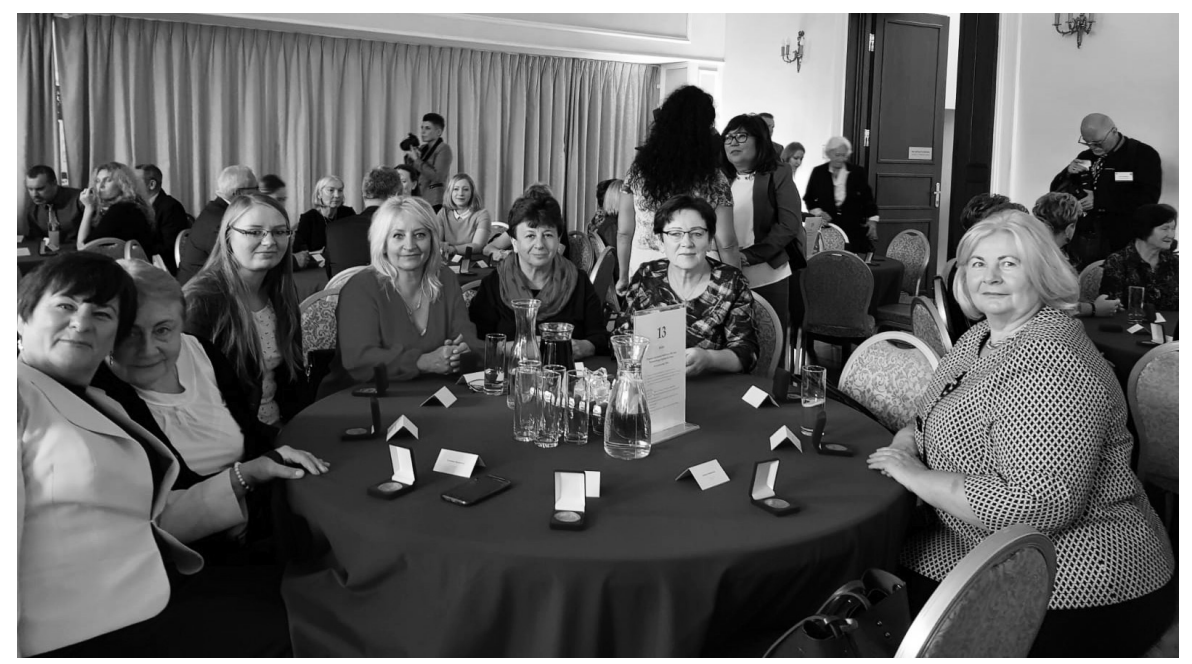

Fot. 4. Wyróżnieni pracownicy Bloku Operacyjnego. Fot. Renata Gut 
Jubileusz 150-lecia Warszawskiego Szpitala dla Dzieci był nie tylko okazją do wspomnień, powrotu pamięcią do ubiegłych lat, ludzi, którzy oddali swoją wiedzę i czas dla chorych pacjentów, ale także spojrzeniem w przyszłość, pokazaniem, że nie tylko samo leczenie jest ważne, istotne jest też to, jak będziemy promować szpital oraz jakie działania podejmiemy na rzecz poprawy zdrowia mieszkańców stolicy. To właśnie te akcje oraz porady i leczenie wiążą warszawiaków $\mathrm{z}$ pierwszym szpitalem dziecięcym na ziemiach polskich. 